Tér és Társadalom 21. évf. 2007/1. 103-115. p.

Tér és Társadalom

XXI. évf. 2007 1: 103-115

\title{
NEURÁLIS HÁLÓZATOK A TÉRSÉGI TIPIZÁLÁSBAN
}

\author{
(Neural Networks in Regional Researches)
}

\author{
FARKAS JENŐ ZSOLT
}

Kulcsszavak:

neurálishálózatok térségtipizalás vidékfejlesztés kistérségek

A tanulmány egy új kvantitatív elemzési módszer geográfiai felhasználásának lehetōségeit tekinti át. Az elsõ részben bemutatja a mesterséges neurális hálózatok néhány jellemzōjét, valamint felhasználási területüket a földrajzban és rokontudományaiban. A második részben egy vidékföldrajzi kutatás során elvégzett számítási kísérlet eredményét ismerteti. Ebben a „hagyományos" statisztikai módszerrel készült vidéktípus meghatározás mellett a kistérségek csoportokba sorolására (klaszterezésére) Kohonen-féle önszervezödô mesterséges neurális hálózatot használ.

\section{Bevezetés}

Napjaink ,információs” társadalmára - a számítástechnika robbanásszerü fejlödésének következtében - jellemző az adatok, elektronikus dokumentumok egyre gyorsuló ütemủ keletkezése és persze ezek megőrzése. Ennek köszönhetően mind az üzleti, mind a tudományos életben hatalmas adattárak alakultak ki, melyekből idő és képzett munkaerỏ hiányában az esetlegesen bennük meglévő hasznos tudást sem tudjuk kinyerni. A híres futurológus John Naisbitt szerint az információs társadalom egyik legnagyobb ellentmondása, hogy „fuldoklik az információban, miközben éhezik a tudásra"'. Az idézetben az ellentmondás csak látszólagos, hiszen az adat az elemzés során válik információvá, míg az információ feldolgozás után alakul tudássá.

Az adatok információvá alakításának hagyományos módja a manuális elemzés, mely lassú, drága és szubjektív. Az elmúlt években ezen átalakítási folyamatban új módszerek és elemző tevékenységek jelentek meg, melyeket összefoglalóan adatbányászatnak vagy angolul ,data mining"-nak is nevezünk (Abonyi 2006). Más megfogalmazás szerint ugyanez: nagy adatbázisokban rejlő hasznos, elözőleg nem ismert információ félautomatikus feltárását jelenti mesterséges intel ligencia alkalmazásával.

Jelen tanulmányunkban egy ilyen új módszer geográfiai felhasználásának lehetőségeit kívánjuk áttekinteni. Az elsỏ részben bemutatjuk a mesterséges neurális hálózatok néhány jellemzőjét, valamint felhasználási területüket a földrajzban és rokontudományaiban. A második részben egy vidékföldrajzi kutatás ${ }^{3}$ mellett elvégzett számítási kísérlet eredményét ismertetjuik. Ebben a „hagyományos” statisztikai módszerrel készültt vidéktípus meghatározás mellett a kistérségek csoportokba sorolására (klaszterezésére) Kohonen-féle önszerveződő mesterséges neurális hálózatot használtunk. 


\section{A mesterséges neurális hálózatok felépitése és tanítása}

A mesterséges neurális hálózatok az adatbányászati eljárások egyik nagy osztályát alkotják. Közös jellemzőjük, hogy az elsőként Cajal által 1909-ben a gerincesek tanulmányozása során leírt neuron felépítést és idegrendszert imitálják. Az ember és a gerinces állatok - idegrendszere neuronokból épül fel, és ezek képezik az információfeldolgozás alapvető részegységeit. Az emberi gondolkozás fiziológiájának kutatása során tudósok rájöttek, hogy az idegrendszernek vannak bejövő ingereket összegyűjtő, majd bizonyos feldolgozás után a jelet továbbító ágai. Az átadási folyamat egészen addig tart, míg az ingerületek el nem érik azokat az idegsejteket, amelyek a kérdéses ingerre adott válaszért felelősek. A válasz milyensége két dologtól függ: egyrészt örökletes tényezőktől, másrészt az egyén élete során megszerzett tapasztalataitól és tudásától. Ennek felismerése azért lényeges, mert azt jelenti, hogy ez a struktúra adaptív, vagyis képes a bementi adatokhoz tanulással alkalmazkodni (Sárközy é.n.).

W. S. McCulloch és W. Pitts 1943-ban elkészítette a neuron matematikai modelljét, amely a Threshold Logic Unit (TLU) nevet kapta. A TLU-ban minden egyes bemenethez rendelhetô egy súly, majd a súlyozott bemenetek összege a neuron átviteli függvényén keresztül adja a kimenetet.

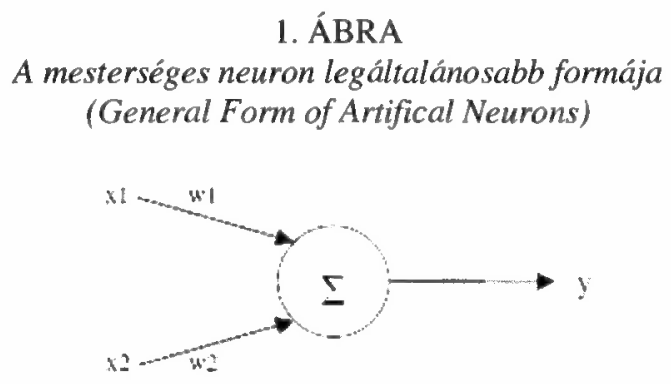

Forrás: Lasztovica (é.n.).

Az így felépített mesterséges neuronok összekötésébỏl kapjuk a mesterséges neurális hálózatokat. Az elsö komolyabb eredmények az 1950-es évek végén és az 1960-as évek elején születtek, majd nem sokkal ezután feledésbe is merulltek. A neurális hálózatok újrafelfedezése akkor kezdődött, amikor az 1980-as évek elején leírták a tanításukra alkalmas, ún. hibavisszaterjesztéses algoritmust (backpropagation algorithm, 1986-ban publikálta D.E. Rumelhart, G.E. Hinton és R.J. Williams). Ezzel lehetővé vált a természetes rendszerek analógiájára mesterséges neurális hálózatok létrehozása információfeldolgozás céljára.

A mesterséges neurális hálózatok rétegekből épülnek fel. Általában valamennyi réteg összes neuronja az elötte és az utána álló réteg összes neuronjával kapcsolatban van, a saját rétegének neuronjaival azonban nincs. A bemenő réteg annyi neuronból áll, ahány bemenő változónk van. Ezek lényegében csak ,jeltovábbítást" végeznek a többi csomópont felé. A rejtett rétegben találhatók a „rejtett neuronok” 
(számuk tetszóleges lehet), amelyeknek mind a bemenete, mind a kimenete másik csomóponthoz kapcsolódik. Ebben a rétegben folyik a tulajdonképpeni adatfeldolgozás. Egy hálózaton belül több rejtett réteg is lehet, azonban kettőnél többre nincs szükség, mivel matematikailag bizonyított, hogy két réteggel bármely folytonos függvény közelíthetö (Kenesei 2006). A kimeneti rétegben annyi neuron van, ahány kimeneti változónk van. Ezek továbbítják az információt a „külvilág” felé.

2. ÁBRA

$M L P$ hálózat vázlata

(The Scheme of $M L P$ )

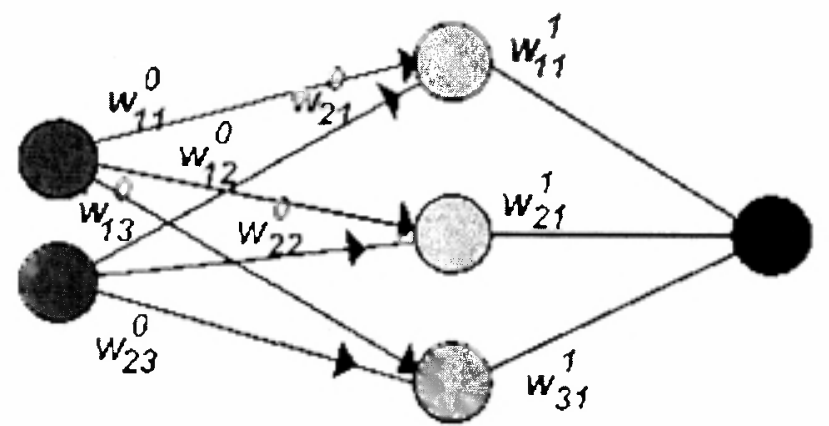

bemeneti réteg

kimeneti réteg

Forrás: Sárközy (é.n.).

Mint arról a neurális hálózatok felépítésénél már esett szó, az ilyen típusú hálózatok tanítási-tanulási folyamat után alkalmazhatók különböző feladatok megoldására. Tanulásuk módszere két fajta lehet: ellenőrzött vagy nem ellenőrzött. Az ellenőrzött tanulás esetében a célunk az, hogy a tanítandó hálózat múködése minél jobban közelítse a vizsgált rendszer müködését, tehát egy adott bemenet esetén tudjuk, hogy mit várunk a kimeneten. Így a hálózat válaszát össze tudjuk hasonlítani a kívánt vagy elvárt válasszal. A gyakorlatban ez azt jelenti, hogy a csomópontok közötti súlyokat addig változtatjuk, amíg a kimeneti eredmények egyre jobban megközelítik az elérni kívánt valós értékeket.

A „nem ellenörzött tanulás” esetén nincsenek összetartozó be- és kimeneti adatpárok. A hálózatnak a bemenetek alapján kell valamilyen viselkedést kialakítani. Általában a hálózatoknak valamilyen összefüggéseket, hasonlóságokat kell felderíteniük a bemeneti adatokban. Ezeket a hálózatokat hívják önszerveződő (selforganized map, SOM) hálózatoknak is (Lasztovicza é.n.).

\section{A mesterséges neurális hálózatok alkalmazása}

Gyakorlati alkalmazásaik az alábbi feladattípusokra vezethetőek vissza: osztályozási, optimalizálási, approximálási és a nemlineáris dinamikus rendszerek elemzésének feladataira. A konkrét alkalmazásokat tekintve 1990-ig javarészt csak katonai 
felhasználásról beszélhetünk, mint pl.: a cirkálórakéták célpont-azonosítási rendszerei. Ennek köszönhetően terjedtek el a civil életben is a neurális hálózatokra alapuló azonosítási problémákat megoldó felhasználások, mint például a hang és arc identifikáció, vagy a biológiában az egyed, ill. a faj felismerés. E technológia másik nagy felhasználója az üzleti élet, ahol a raktárkészletek tervezésétől a részvény árfolyam elörejelzésig terjed az alkalmazásuk spektruma.

A földrajz rokontudományai közül a térinformatikában a mesterséges neurális hálózatok már elterjedt módszernek számítanak. Két feladattípust kell kiemelnünk a felhasználási körükböl: az egyik a térbeli interpolációk köre, a másik különbözö osztályozási feladatok megoldása. A térbeli interpolációra példa egy háromszögelési hálózat alappontjainak süritése vagy egy tó felszíni vízhőmérsékletének adott pontban történő meghatározása (természetesen „tanuló adatok” feldolgozása után). Az osztályozási feladatok leggyakrabban légifényképeken vagy müholdképeken a különbözỏ tájhasználati (felszínborítási) foltok tartalmi meghatározását, illetve objektumok és tárgyak azonosítását jelentik.

Földrajzi kutatások köréből is tudunk példát hozni a mesterséges neurális hálózatok alkalmazására. Ezekben jellemzően időben változó térbeli folyamatok elörejelzésére használták a módszert. Az egyik ilyen vizsgálatban az erdöterületek csökkenését modellezték (Mas-Puig-Palacio-Sosa-López 2004).

A kutatás során a mintaterületen két idöpontra határozták meg az erdőterületek kiterjedését. A két térképböl „levezettek” egy harmadik erdőterület változás térképet. A „változás térkép” alapján meghatározták azokat a tényezőket, amelyek leginkább befolyásolták az erdőterületek csökkenését. Ezután az alkalmazott neurális hálózatot betanították a „változás térkép” és a kiválasztott mutatók alapján. Majd a tanítási folyamat után egy harmadik időpontra készítettek előrejelzést. Utolsó lépésként az elörejelzést összehasonlították a valós erdősültséggel. Végkövetkeztetésként megállapították, hogy ez a fajta megoldás nagy pontossággal jelzi elóre az erdőterületek csökkenését. Hasonló módszert alkalmaztak kutatók a földhasználat változásainak elörejelzésére is (Pijanowski-Brown-Shellito-Manik 2002). Ebben a kutatásban az 1980-as, 1990-es és a 2000-es állapotból különböző tényezők figyelembevételével próbálták a 2010-es és 2020-as várható földhasználatot modellezni.

\section{Mesterséges neurális hálózatok a térségi tipizálásban}

Vidékföldrajzi vizsgálatunk célja olyan kistérség-típusok meghatározása volt, amelyek az európai terület- és vidékfejlesztés tervezési és beavatkozási térségmeghatározási mintáinak megfelelően sokoldalúan sorolják be a kistérségeket. A munkát két dokumentumra: a Tanács „Community strategic guidelines for rural development (programming period 2007 to 2013) (2006/144/EC)" címủ határozatára (valamint ennek módszertani mellékletére), illetve az Európai Unió ESPON programjának az „Urban-rural relations” címü átfogó kutatási jelentésére alapoztuk. Módszertani szempontból a típusokat, és a meghatározás módját a Helsinki Mủszaki Egyetem által az ESPON jelentésben leírt metódus alapján végeztük el (természetesen 
ahol szükséges volt a magyarországi viszonyokhoz igazítva). Az eredmény értékelése után azonban felmerült, hogy jó lenne a rendelkezésre álló adatbázis felhasználásával egy másfajta csoportosítást is elvégezni, amely esetleg visszaigazolná az eddigi következtetéseket és új összefüggéseket tárna fel.

A kísérlethez a már meglévő 37 mutatóból álló adatbázist használtuk fel. A feladat megoldására az ún. Kohonen-féle „önszerveződő, mesterséges neurális hálózat" metodikáját alkalmaztuk. Választásunk azért esett erre a módszerre, mert a mértékegységükben, dimenzióikban eltérö numerikus input adatok feldolgozását is lehetővé teszi, illetve mert a szakirodalom szerint jobb eredményt adhat a hagyományos statisztikai vagy más sokváltozós eljárásoknál (Openshaw-Wymer 1995).

E hálózatok jellemzője, hogy három rétegből állnak, azonban a feldolgozást végzö réteget a feltalálója Teuvo Kohonen finn professzor után Kohonen-rétegnek hívjuk. Kohonen ezt a réteget a felügyelet nélküli klaszterező módszere számára dolgozta ki 1982-ben. Lényege, hogy az n-dimenziós bemenő adatokat szabályos kétdimenziós tömbökre képezi le. Ezt úgy éri el, hogy az n-dimenziós bemeneti adatér egymáshoz hasonló vektorainak olyan neuronokat feleltet meg a neurontérképen, amelyek egymáshoz szintén közel helyezkednek el euklideszi távolságukat tekintve (Fogarassyné Vathy 2006). Az általunk felhasznált szoftver egy Excel munkafüzet alá fejlesztett Visual Basic alkalmazás ${ }^{4}$ volt.

\section{TÁBLÁZAT Demográfiai adatok \\ (Demographic data)}

\begin{tabular}{|c|c|c|}
\hline Megnevezés & $E^{\prime} v$ & Mértékegység \\
\hline Lakónépesség & 2000 & fö \\
\hline Lakónépesség & 2004 & fö \\
\hline Lakónépesség változása 2000-ről 2004-re & $2000-2004$ & $\%$ \\
\hline Népsürủség & 2004 & fö $/ \mathrm{km}^{2}$ \\
\hline $\begin{array}{l}\text { Természetes szaporodás évi átlaga 2000-2004 között } \\
\text { ezer före }\end{array}$ & $2000-2004$ & fö \\
\hline Vándorlási különbözet évi átlaga 2000-2004 ezer före & $2000-2004$ & fö \\
\hline 0-14 évesek aránya a népességben & 2004 & $\%$ \\
\hline 60-x évesek aránya a népességben & 2004 & $\%$ \\
\hline Vitalitási index & 2004 & \\
\hline $\begin{array}{l}\text { Városi lakosság aránya a kistérségben } \\
120 \text { fö/km²-nél sủrübb településeken lakók aránya a }\end{array}$ & 2004 & $\%$ \\
\hline $\begin{array}{l}\text { kistérségben (urbanitási index) } \\
10000 \text { fönél népesebb településeken lakók a }\end{array}$ & 2004 & $\%$ \\
\hline kistérségben & 2004 & $\%$ \\
\hline $1 \mathrm{~km}^{2}$ belterületre jutó lakosok száma & 2004 & fö $/ \mathrm{km}^{2}$ \\
\hline Átlagos iskolai végzettség & 2001 & osztály \\
\hline Külterületi népesség aránya & 2001 & fö $/ \mathrm{km}^{2}$ \\
\hline
\end{tabular}

Forrás: KSH. 
A vizsgálat során alkalmazott adatbázis összeállítását egyrészt a Helsinki Müszaki Egyetem által az ESPON keretében alkalmazott módszertan alapján, másrészt az MTA RKK Alföldi Tudományos Intézetében végzett korábbi kutatások adatainak és eredményeinek felhasználásával végeztük (Csatári 1996). Az adatbázisba végül 37 mutató került négy tematikus egységbe rendezve. Kiválasztásuknál ùgyeltünk arra, hogy azok a környezet és a társadalom térbeli jelenségeinek és folyamatainak minél szélesebb körét lefedjék. Az első csoportba a népesség és a demográfia föbb adatai kerültek (1. táblázat).

Az ESPON vizsgálat módszertanához igazodva a megszokott jelzőszámok mellett alkalmaztuk a belterületi népsủrúség mutatót, melyet a 2001-es népszámlálás belterületi lakónépesség-száma és az $\mathrm{OTAB}^{5}$ települési belterület fedvényének területe alapján számítottunk ki térinformatikai eszközökkel.

A következö mutatócsoportba a foglalkozási és foglalkoztatottsági adatok kerültek (2. táblázat).

2. TÁBLÁZAT

Foglalkozási és foglalkoztatottsági adatok

(Employment)

\begin{tabular}{lcc}
\hline \multicolumn{1}{c}{ Megnevezés } & Év & Mértékegység \\
\hline Mezögazdasági foglalkoztatottak aránya & 2001 & $\%$ \\
Ipari foglalkoztatottak aránya & 2001 & $\%$ \\
Tercier foglalkoztatottak aránya & 2001 & $\%$ \\
Munkanélküliek aránya a lakónépességben & 2004 & $\%$ \\
Tartós munkanélküliek aránya a munkanélküliekben & 2004 & $\%$ \\
\hline
\end{tabular}

Forrás: KSH.

3. TÁBLÁZAT

Gazdasági és infrastruktuira adatok

(Economy and Infrastucture)

\begin{tabular}{lcc}
\hline \multicolumn{1}{c}{ Megnevezés } & $E^{\prime} v$ & Mértékegység \\
\hline Regisztrált társas vállalkozások 1000 före jutó száma & 2004 & $\mathrm{db}$ \\
Regisztrált egyéni vállalkozások 1000 före jutó száma & 2004 & $\%$ \\
1 km²-re jutó vállalkozások száma & 2004 & $\mathrm{db} / \mathrm{km}^{2}$ \\
1 adófizetöre jutó éves nettó jövedelem & 2001 & $\mathrm{Ft}$ \\
Müködö mezögazdasági vállalkozások száma 1000 före & 2003 & $\mathrm{db}$ \\
Közüzemi vízhálózatba kapcsolt lakások aránya & 2004 & $\%$ \\
1 km vízvezetékre jutó csatornahálózat hossza & 2004 & $\mathrm{~km}$ \\
Személygépkocsik száma 1000 före & 2004 & $\mathrm{db}$ \\
Kiskereskedelmi boltok száma 1000 före & 2004 & $\mathrm{db}$ \\
Kábeltelevíziós hálózatba kötôttt lakások aránya & 2004 & $\%$ \\
Vendégéjszakák száma 1000 fóre & 2004 & vendégéjszaka \\
1 km²-re jutó utak és vasutak hossza & 2004 & $\mathrm{~km} / \mathrm{km}^{2}$ \\
\hline
\end{tabular}

Forrás: KSH, APEH. 
A harmadik csoportot a gazdaságra és az infrastruktúrára vonatkozó mutatók alkották (3. táblázat). A korábbi magyarországi elemzésekhez képest itt új elemként jelenik meg - az ESPON vizsgálatot követve - a közlekedési hálózat sürüsége $\left(\mathrm{km} / \mathrm{km}^{2}\right)$, mely adatokat az OTAB részét képező közút- és vasúthálózat adataiból, szintén térinformatika segítségével Intézetünk számítógépein állítottunk elő.

A társadalom és a gazdaság bemutatását szolgáló mutatók után a környezetre, azon belül is részben annak állapotára, részben annak használatára vonatkozó utolsó adatcsoport került meghatározásra. Az Európai Unió ilyen jellegü adatok gyüjtésének céljából indította el 1985-ben az ún. CORINE ${ }^{6}$ programot. Ennek célja szisztematikus környezeti és területhasználati információk gyüjtése, az Európai Unió különböző ágazati politikáinak alátámasztására. A Helsinki Műszaki Egyetem által végzett elemzésben is ezek az adatok kerültek felhasználásra. Intézetünkben a legújabb állapotokat tükröző 2000-es adatokat használtuk (4. táblázat).

\section{TÁBLÁZAT}

Felszínborítás és földhasználat adatok

(Landcover and Landuse)

\begin{tabular}{lcc}
\hline \multicolumn{1}{c}{ Megnevezés } & $E^{\prime} v$ & Mértékegység \\
\hline Mesterséges felszínek aránya & 2000 & $\%$ \\
Mezőgazdasági területek aránya & 2000 & $\%$ \\
Erdőterületek aránya & 2000 & $\%$ \\
Természetközeli területek aránya & 2000 & $\%$ \\
\hline
\end{tabular}

Forrás: European Environmental Agency, Copenhagen, 2005.

Az általunk végzett analízis során első alkalommal az összes kistérséget egyszerre vizsgáltuk. Ennek eredményeként négy csoportot kaptunk. Az első osztályba a fỏváros került, a másodikba további két térség. Ezt az eredményt nem találtuk kielégítőnek a részletes elemzéshez és interpretációhoz, így e három kistérség adatait kivettuik az adatbázisból. Ezután egy új elemzést végeztettünk a hálózattal, melynek során szintén négy csoport alakult ki. A végeredményben a fỏvárost értelemszerủen külön osztályként hagytuk meg, míg a két térséget a második analízis első osztályába tettük. A további két csoportot a második elemzés során kialakult eredmény képezte. A vizsgálat végén kapott eredményt a 4. táblázat és az 5. ábra mutatja.

$\mathrm{Az}$ első „osztályt” egyedül a főváros képezi a többi térségtől minőségileg és mennyiségileg is eltérỏ volta miatt. A 2. kategóriába lényegében a régióközpontok, az egri kistérség és Budapest közvetlen agglomerációjának területe került. Érdemes kiemelni, hogy Budapest körül két gyürü alakult ki. Az első egy közvetlenül hozzá kapcsolódó városi gyürü (alvóvárosok, a város müködését biztosító logisztikai és termelési központok), míg a második ,átmeneti” típusú terưletekből áll az első gyürüt övezve. E második gyürü az agglomerációhoz egyre szorosabban kapcsolódó területeket jelöli ki, amelyek egyébként egyértelmủen az e módszerrel kapott „városi 
típus" irányába fejlödnek. E területek déli határa a kecskeméti kistérségig nyúlik, a fỏvárostól mintegy $90 \mathrm{~km}$-re.

A tipikusan vidéki és városi térségtípusok között leirható, úgynevezett „átmeneti jellegư” területek másik része a Dunántúlon, a Balaton környékén, a nyugati határmentén, illetve az Északi-középhegység területén található. Ennek okai részben az államszocializmus ipartelepítési politikájában, másrészt a rendszerváltás utáni gazdasági hatásokban keresendők. A következö kategóriába - a jellemzőik alapján - az egyértelmüen vidékinek tekinthetö térségek kerültek. Ide tartozik a 168 kistérségből 105, az ország 10 millió lakosából 3,5 millió.

\section{TÁBLÁZAT}

A neurális hálózat által kialakított térségtípusok összefoglaló adatai (Results of Analysis: Regional Clusters)

\begin{tabular}{|c|c|c|c|c|c|}
\hline Adat / térésgtípus & Föváros & $\begin{array}{l}\text { Városi } \\
\text { térs. }\end{array}$ & $\begin{array}{c}\text { Átmeneti } \\
\text { térs. }\end{array}$ & $\begin{array}{l}\text { Vidéki } \\
\text { térs. }\end{array}$ & $\begin{array}{c}\text { Országos } \\
\text { adat }\end{array}$ \\
\hline $\begin{array}{l}\text { Lakónépesség clusterek szerint } \\
\text { (fö) }\end{array}$ & 1697343 & 2048230 & 2858410 & 3493566 & 10097549 \\
\hline $\begin{array}{l}\text { Adott típusba tartozó térségek } \\
\text { száma (db) }\end{array}$ & 1 & 15 & 47 & 105 & 168 \\
\hline $\begin{array}{l}\text { Lakónépesség (2004) átlaga } \\
\text { (fö) }\end{array}$ & 1697343 & 136548,67 & 60817,23 & 33272,06 & 60104,46 \\
\hline Népsürüség átlaga (fö/km²) & 3232,30 & 306,34 & 121,03 & 58,38 & 116,94 \\
\hline $\begin{array}{l}\text { Városi lakónépesség arányá- } \\
\text { nak átlaga (\%) }\end{array}$ & 100,00 & 73,57 & 59,21 & 43,02 & 50,62 \\
\hline $\begin{array}{l}\text { Mezögazdasági foglalkoztatot- } \\
\text { tak arányának átlaga (\%) }\end{array}$ & 0,52 & 2,27 & 4,49 & 11,81 & 8,84 \\
\hline $\begin{array}{l}\text { Ipari foglalkoztatottak arányá- } \\
\text { nak átlaga (\%) }\end{array}$ & 21,27 & 31,11 & 39,36 & 36,94 & 37,00 \\
\hline $\begin{array}{l}\text { Tercier foglalkoztatottak } \\
\text { arányának átlaga (\%) }\end{array}$ & 78,21 & 66,62 & 56,15 & 51,25 & 54,16 \\
\hline $\begin{array}{l}\text { Egy adófieztőre jutó nettó } \\
\text { jövedelem átlaga }(\mathrm{Ft})\end{array}$ & 987427 & 801027 & 713513 & 599555 & 651733 \\
\hline $\begin{array}{l}\text { Munkanélküliek arányának } \\
\text { átlaga (\%) }\end{array}$ & 1,32 & 2,52 & 3,67 & 6,41 & 5,27 \\
\hline $\begin{array}{l}\text { Mesterséges felszínek arányá- } \\
\text { nak átlaga (\%) }\end{array}$ & 66,78 & 13,46 & 7,04 & 4,20 & 6,19 \\
\hline $\begin{array}{l}\text { Mezögazdasági területek } \\
\text { arányának átlaga (\%) }\end{array}$ & 18,84 & 55,35 & 58,30 & 70,67 & 65,53 \\
\hline Erdőterületek arányának átlaga & 9,08 & 24,62 & 25,08 & 18,06 & 20,55 \\
\hline $\begin{array}{l}\text { Külteruileti népesség arányá- } \\
\text { nak átlaga }(\%)\end{array}$ & 0,35 & 2,36 & 2,69 & 3,94 & 3,43 \\
\hline
\end{tabular}

Forrás: Saját szerkesztés. 
Farkas Jenő Zsolt : Neurális hálózatok a térségi tipizálásban. Tér és Társadalom 21. évf. 2007/1. 103-115. p.

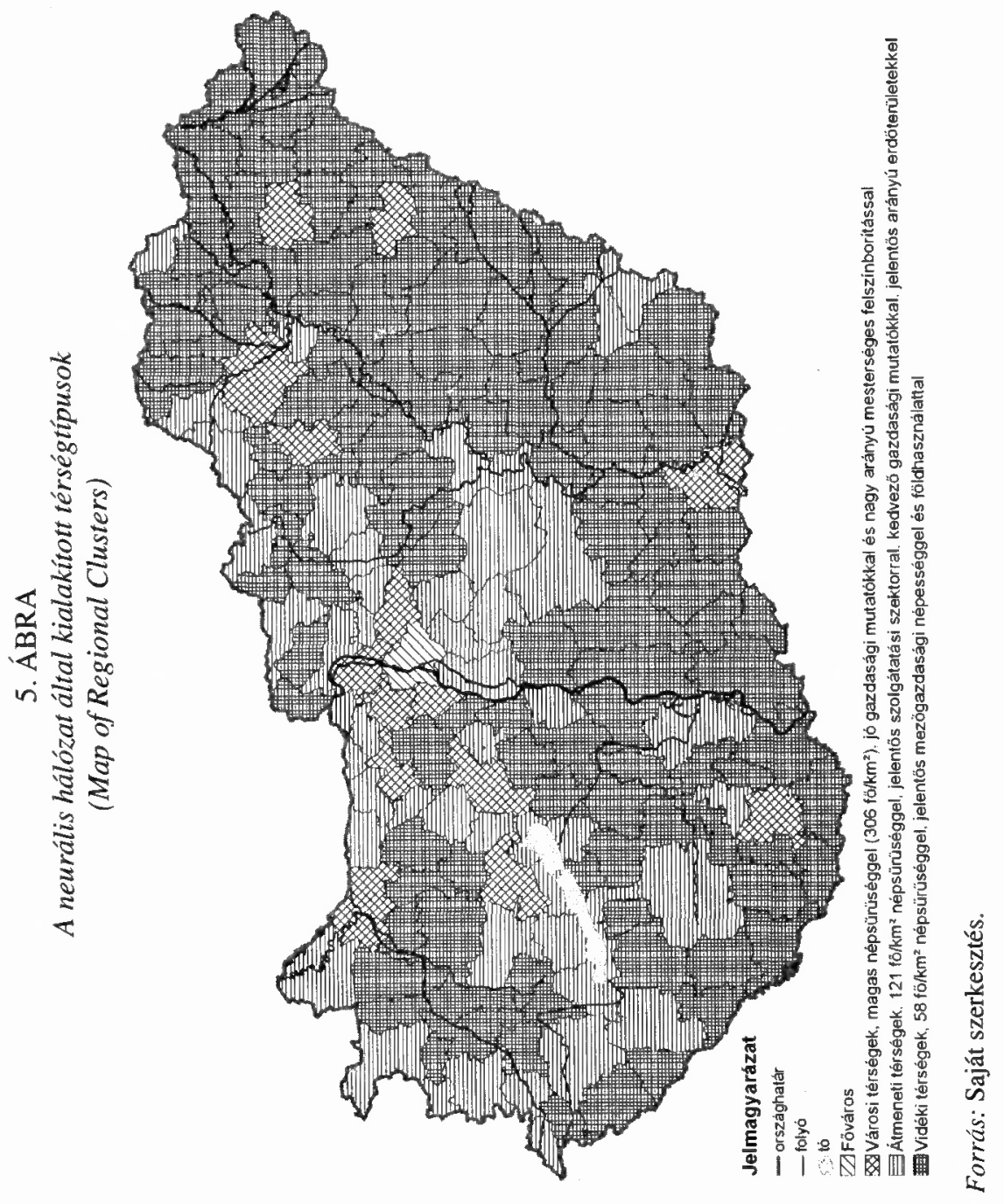


Az így meghatározható városi térségek ( 15 térség, több mint 2 millió lakossal) az országos átlagot csaknem háromszor meghaladó népsürüségüek $\left(306 \mathrm{fö} / \mathrm{km}^{2}\right)$. Bennük a városi népesség aránya 73\% (országosan csak 50,62\%), a humán erőforrásaik képezettsége jelentősen meghaladja az országos átlagot, a tercier foglalkoztatottak aránya $66 \%$ (országos adat 54\%), átlagosan 200 ezer Ft-tal magasabbak az egy före jutó jövedelmek, mint a vidéki típusú térségekben, s így kedvező munkanélküliségi mutatókkal rendelkeznek. Magas a társas vállalkozások és az egyéni vállalkozások 1000 före jutó száma, a fỏváros után itt a legmagasabb az 1000 före jutó személygépkocsik száma. A mesterséges felszínek aránya e térségekben 13\% átlagosan, s az országos átlagnál 50\%-kal sürübb közlekedési hálózattal rendelkeznek.

$\mathrm{Az}$ átmeneti térségek (47 térségben, 2 millió 860 ezer fö él) állapotleírása szerint a népsürüség az országos átlag körüli $\left(120\right.$ fö/ $\left./ \mathrm{km}^{2}\right)$, a városi népesség aránya $59,2 \%$, 14\%-kal kevesebb, mint a városinak minősített kistérségekben, az egy före jutó átlagos nettó jövedelem átlagosan 100 ezer Ft-tal magasabb, mint a vidéki térségekben, a munkanélküliségi mutatók rosszabbak, mint a városi területeken. Itt a legmagasabb az 1000 före jutó vendégéjszakák száma (3599éj), a mesterséges felszínek aránya csak $7 \%$.

A vidéki térségek jellemzői (105 kistérség, 3 millió 500 ezer lakos) közül kiemelésre kívánkozik, hogy a népsürüségük az országos átlag fele $\left(58 \mathrm{fö} / \mathrm{km}^{2}\right)$, a városi népesség aránya $43 \%$ (tehát a városlakók a kisebbséget alkotnak ebben a kategóriában). Általában a gazdasági és jövedelmi mutatókat tekintve a legkedvezőtlenebb helyzetben lévő területek, a mezőgazdaságban foglalkoztatottak átlagos aránya $12 \%$, az egy före jutó nettó jövedelem 50 e Ft-tal az országos átlag alatt van, magas a munkanélküliek aránya, ill. ezen belül is jelentős a tartósan munkanélkülieké, a mủködő mezőgazdasági vállalkozások aránya ebben az osztályban a legmagasabb. A mesterséges felszínek aránya csak $4 \%$, a mezőgazdasági földhasznosítású területek aránya e kistérségekben több mint 70\%. A külterületi népesség aránya országos átlag feletti, átlagosan $4 \%$.

\section{Összegzés}

A módszer értékelését két lépcsőben végezhetjük el. Első lépcsőben értékelhetjük a Kohonen-féle hálózat által kialakított csoportokat. Ez alapján megállapíthatjuk, hogy az egyes csoportok homogén képet mutatnak, így azokat könnyü volt megfelelỏ értelmezö címkékkel ellátnunk.

A második lépcsőben összevethetjük az eredményt más, korábbi vizsgálatok eredményével, melyekröl általában azt mondhatjuk, hogy azoktól jelentősen nem tér el. Ennek alátámasztására ismertetnénk az ESPON térség-típusokkal történt összevetést. Mindenekelött azonban meg kell jegyeznünk, hogy a két vizsgálat ,abszolút jóságát" a társadalomtudományokban megítélni rendkívül nehéz. Másrészt a két elemzés végén megállapított térségtípusok tartalmilag nem teljesen fedik egymást. Ezért a pontos összehasonlíthatósághoz meghatároztuk, hogy az egyes típusok mennyire felelnek meg egymásnak. 


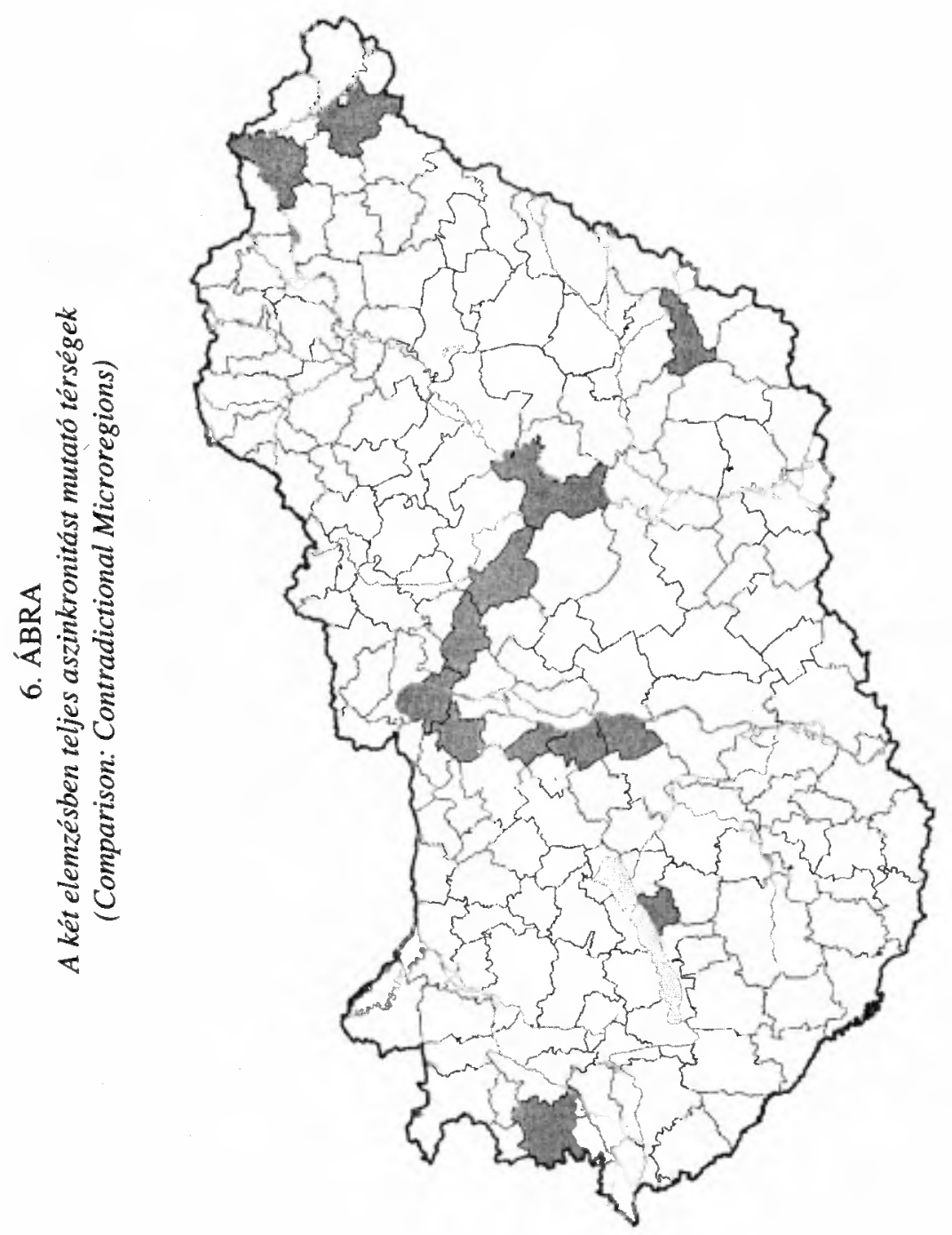

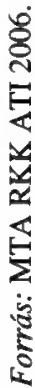


Az összevetésekor azt állapítottuk meg, hogy a két módszer végeredménye 130 kistérség esetében - az adott keretek között - megegyezik. Ez 77,3\%-os egybeesést jelent. További 24 esetben részben (14,2\%) és 14 esetben egymásnak ellentmondónak tünik a két módszer által kapott eredmény.

Az utóbbiak között mind megyeszékhelyek térségei (Szombathely, Szolnok, Békéscsaba) mind az agglomerációban fekvő kistérségek (Gödöllői, Pilisvörösvári, Adonyi, Szentendrei), mind néhány alföldi városi kistérség (Mátészalka, Kisvárda) megtalálható.

S bár ezek külön-külön az egyes elemzésekben ,jó helyen” vannak, az összevetésben fellehető „meg nem felelésük” a térbeli fejlödésük olyan valószínűsíthető különlegességére utal, amit további elemzésekkel kellene vagy lehetne kimutatni.

A Kohonen-féle önszervezödö hálózatokról mint módszerröl azonban megállapíthatjuk, hogy földrajzi kutatásokban felmerülő csoportosítási feladatok elvégzésére legalább olyan jól használható, mint a hagyományos statisztikai metódusok, vagy mint a faktor-és klaszteranalízis.

\section{Jegyzetek}

${ }^{1}$ Csatári B.-Farkas J. Zs. Vidéktípusok. Kézirat megjelenés alatt.

${ }^{2}$ Idézi Abonyi J. 2006, 6. o. Eredeti: John Naisbitt: Megatrends, Warner Books, 1982.

${ }^{3}$ Csatári B.-Farkas J. Zs. Vidéktípusok. Kézirat megjelenés alatt.

${ }^{4}$ Fejlesztő: Angshuman Saha, letölthető: http://www.geocities.com/adotsaha/NN/SOMinExcel.html címről.

${ }^{5}$ Országos Térképészeti Alapadatbázis

${ }^{6}$ Coordination of Information on the Environment

${ }^{7}$ The European Spatial Planning Observation Network

\section{Irodalom}

Abonyi J. (2006) Adatok feltáró jellegü elemzése és megjelenítése. - Abonyi J. (szerk.) Adatbånyászat a hatékonyság eszköze. Computerbooks, Budapest. 5-40. o.

Angshuman Saha (é.n.) Neural Network Models in Excel for Prediction and Classification. http://www.geocities.com/adotsaha/NNinExcel.html

Csatári B. (1996) A magyarországi kistérségek néhány jellegzetessége. MTA RKK Alföldi Tudományos Intézete, Kecskemét. http://www.rkk.hu/regional/tan/beavatk.html

ESPON jelentések (2005) http:/www.espon.eu/mmp/online/website/content/projects/259/649/index_EN.html

Fogarassyné Vathy Á. (2006) Csoportosítás (klaszterezés). - Abonyi J. (szerk.) Adatbányászat a hatékonyság eszköze. Computerbooks, Budapest. 131-182. o.

Kenesei T.P. (2006) Regressziós technikák. - Abonyi J. (szerk.) Adatbányászat a hatékonyság eszköze. Computerbooks, Budapest. 273-292. o.

Lasztovicza L. (é.n.) A neurális hálózatok alapjai. http://home.mit.bme.hu/ laszto/web_data/neural/ nn_basics.PDF

Mas J.F.-Puig H.-Palacio J.L.-Sosa-López A. (2004) Modelling deforestation using GIS and artificial neural networks. - Environmental Modelling and Software. 19. 461-471. o.

Openshaw S.-Wymer C. (1995) An emprirical study of a neurocomputing classifier of large spatial census dataset for small areas. -Fischer M.M.-T.T. Sikos-L. Bassa (eds.) Recent developments in spatial information, modelling and processing. Geomarket. Budapest. 44-71. o.

Pijanowski B.C.-rown D.G.-Shellito B.A.-Manik G.A. (2002) Using neural networks and GIS to forecast land use changes: a Land Transformation Model, Computer, Environment and Urban Systems. 26. 553-575. o.

Sárközy F. (é.n.) Térinformatika. http://gisfigyelo.geocentrum.hu/sarkozy_terinfo/tbev.htm 


\section{NEURAL NETWORKS IN REGIONAL RESEARCHES}

Electronically storaged datas and documents boost in an accelerating way in nowadays Information Society due to the revolution in computer technology. Nevertheless there is no time and manpower to process these datas by conventional manual analysis. This problem has been solved with some new analytical methods applied in the past few years. In general they are called data mining methods. In this article I give a brief summary on one of these methods: the artificial neural networks. The first part of this essay gives a review about artificial neural networks and their usage in GIS and geography. In the second part I describe the clusterization of Hungarian small regions with a Kohonen Self-Organized Map (SOM). The SOM has made four clusters in the analysis. After the investigation, I labelled them as capital city, urban, urban-rural transition and rural regions. The clusters were homogeneous and can be compared against previous reserches such as ESPON ${ }^{7}$ "Urban-rural relations" project. In comparison there was a high level similarity between the outcome of the above clusterizations. Finally, I point out that Kohonen SOM is an acceptable method of grouping in geographical researches. 